


\section{Online folyóirat}

Szerkesztette: VÁGÁNY Judit Bernadett, PhD - FENYVESI Éva, PhD

Borító: FLOW PR

Kiadja: Budapesti Gazdasági Egyetem, Kereskedelmi, Vendéglátóipari és Idegenforgalmi Kar, Közgazdasági és Üzleti Tudományok Tanszék

Felelős kiadó: FENYVESI Éva, PhD

a Közgazdasági és Üzleti Tudományok Tanszék vezetője

ISSN 2630-886X

2020. 


\title{
AZ ELEKTRONIKUS JEGYÉRTÉKESÍTÉS REGIONÁLIS KIHIIVÁSAI A MAGYAR VASÚTNÁL
}

\author{
REGIONAL CHALLENGES OF ELECTRONIC TICKETING
} AT THE HUNGARIAN RAILWAY

ERDEI Attila

Kulcsszavak: vasút, elektronikus kereskedelem, hatékonyság Keywords: rail, electronic commerce, efficiency

JEL kód: R40, R28, O18, L81 


\section{ÖSSZEFOGLALÓ}

Az internet elterjedésével, a kibertér tágulásával egyre fontosabb szerepet kap a javak és szolgáltatások. elektronikus kereskedelme. Ebböl a folyamatból a közösségi közlekedés sem maradhatott ki, mivel a szolgáltatók, akik. idöben ismerték fel a rendszuer elónyeit, illetve megfeleló idöben és módon alkalmazták. azt, hatalmas elönyböz juthattak versenytársaikkal szemben. Az. Amerikai Egyesült Allamokban az 1980-as évek elejétöl vezették be elöször a légitársaságok az elektronikus kereskedelmi megoldásokat, mivel a verseny olyan erös volt, hogy a piaci szuereplöknek minden esžöżt meg kellett ragadniuk, hogy elönyhöz jussanak. Napjainkra a légitársaságok jegyeladásainak döntö többsége elektronikus úton történik. A vasúti közlekedésben is megjelentek az e-jegyek, amelyek európai elterjedésének kezdete a 2000-es évek elejére tehetó. A vasút esetében üj módszereket kellett kidolgozni, elsösorban az eltéró utazási szokások, a nyitott elérés stb. miatt. Természetesen ebben az esetben is legelöször a tökeerös és nagy utasforgalmat lebonyolitó vasúttársaságoknál, mint például a Deutsche Bahn-nál (DB), a Schweizerische Bundesbahnen-nál (SBB), illetve a Sociêté Nationale des Chemins de Fer Français-nál (SNCF) vezették be. A magyar vasúti közlekedésben pár éves késéssel kezudték el alkalmazni az elektronikus kereskedelmi lehetöségeket. Ma már a jegyek és bérletek kevesebb, mint 60\%-át értékesitik jegypénztárakban. 2018-as statisz̨tikai adatok szerint egyre növekszile az alternativ (automata, internet, Vonatinfo) módon értékesitett jegyek, bérletek száma. Tanulmányomban célom vizsgálni az elektronikus jegyértékesitő rendszer bevezetésének kibivásait és alkalmazásának tapaszutalatait a MÁV-START Zrt-nél. Vizsgálatom során jellemzóen sz̨ekunder adatokat, külföldi tudományos eredményeket, valamint a vállalat belsö adatait használom fel.

\section{SUMMARY}

The spread of the Internet and the expansion of cyberspace is playing an increasingly important role in electronic commerce of goods and services. Public transport could not be excluded from this process, as service providers who recognized the benefits of the system on time and applied it in a timely manner were able to gain enormous competitive advantage over their competitors. In the United States, airlines have been introducing electronic commerce solutions for the first time since the early 1980s, as competition was so strong that market players had to grab all the tools to benefit. Today, the vast majority of airline ticket sales take place electronically. In rail transport, e-tickets have also emerged, with the beginning of European distribution in the early 2000s. In the case of the railway, new methods had to be developed, mainly because of the different travel habits, open access, etc. Of course, in this case, too, it was first introduced by capital-intensive and large passenger railway companies such as Deutsche Bahn (DB), Schweizerische Bundesbahnen (SBB) and Société Nationale des Chemins de Fer Français (SNCF). In the Hungarian rail transport, electronic trading opportunities have been introduced with a few years delay. Today, less than 60\% of tickets and tickets are sold at ticket offices. According to the statistics of 2018, the number of tickets and passes sold in alternative (vending machines, internet, Vonatinfo) is increasing. My aim in my study is to investigate the challenges of the implementation of the electronic ticketing system and experience of its application at MAV -START Zrt. During my research I typically use secondary data, foreign scientific results, and internal data of the company. 


\section{BEVEZETÉS}

A közlekedésben az e-jegyek értékesítése, mint forradalmi újítás, elsóként az Amerikai Egyesült Államokban, a repülésiparban jelent meg az 1980-as években. Az United Airlines 1984-ben vezette be kísérleti jelleggel az elektronikus jegyértékesítési szolgáltatást. A kísérleti időszak 6 évig tartott, ezután vezették be élesben ténylegesen ezt a jegyeladási formát.

A légitársaság bátorsága és újító ötlete jelentős előnyt biztosított a versenytársakkal szemben. Az iparág már ebben az időszakban is jelentékeny fejlődésen ment keresztül, fellendülő tendenciát mutatott egészen a 2001-es sajnálatos eseményekig (terrortámadások New York és Washington ellen rapülőgépek segítségével).

Hamarosan a többi légitársaság is feleszmélt, mivel észrevették az elektronikus, papír nélküli jegyértékesítő rendszerekben rejlő hatalmas lehetőségeket (például az eladási, felhasználás követési és számlázási folyamatok elektronikus dokumentálását). Az utasok ezzel az új módszerrel a világ bármely pontjáról online foglalhattak jegyet, fizethettek érte, és kinyomtatás után felhasználhatták e-jegyüket.

A magyar vasúti közlekedésben néhány évvel később kezdték el alkalmazni az elektronikus kereskedelmi lehetőségeket. Kutatásomban célom elemezni az elektronikus jegyértékesítő rendszer bevezetésének kihívásait és alkalmazásának tapasztalatait a MÁVSTART Zrt-nél. Vizsgálatom során jellemzően szekunder adatokat (a vasútvállalat belső adatait) használom fel.

\section{KUTATÁSMÓDSZERTAN}

Munkámban a legfrissebb szekunder adatokból és információkból dolgoztam. A szekunder források jellemzően a MÁV START Zrt. belső adatbázisából származnak.

\section{EREDMÉNYEK}

\section{A hazai vasút és a MÁV-START Zrt. rövid története}

Az első hazai vasútvonalak, a több mint 150 éve történt kiépülése óta, a folyamatosan bővülő magyar vasúthálózat képes volt betölteni az iparosodó társadalom igényeit, közben mintegy motorját képezte a korabeli fejlődésnek.

A magyar vasút I. világháborúig terjedő korszaka szerencsésen egybeesett az országnak az európai gazdasági rendszerbe való intenzív beintegrálódásával és a vasúti szállításnak, mint fejlődésben lévő szállítási ágazatnak nemzetközi viszonylatban is meghatározó, fellendülésben lévő ütemével. Ebben az időszakban az ország, az egyes régiók és települések gazdasági fellendülésének egyik alapfeltétele volt a megfelelő vasúthálózat kiépítése, illetve a vasúti kapcsolat létesítése. Ennek az igénynek megfelelően néhány évtized leforgása alatt jött létre a korabeli Európa egyik legdinamikusabban fejlődő vasúthálózata (VKI, 2005)

A magyar vasúthálózat az európai fejlődéssel szinkronban jött létre és a II. világháború időszakáig folyamatosan lépést tudott tartani a műszaki fejlődéssel (hálózatsűrűség, kétvágányú vonalak aránya, villamosított vonalak aránya, pályára engedélyezett sebesség, 
hézagnélküli felépítmény aránya, nagytömegű sínek aránya, állomások száma, szintbéli útátjárók, mútárgyak, biztosítóberendezés, jármúvek stb.).

Az 1. táblázatban látható, hogy az 1970-es években a személyszállítási adatokban csökkenés kezdődött és - a motorizáció fejlődésével - a vasút folyamatosan kiszorult a hagyományos közlekedési piacról. Az 1990-es évektől a piacgazdaság megjelenésével, a korábban mesterségesen fenntartott gazdasági környezetben lévő vasút összeomlott, mivel a vasúti közlekedést érintő kedvezőtlen hatások egyszerre, egyidejűleg sokkszerűen érvényesültek. Mindezek a vasúti személy- és áruszállítási teljesítmények visszaeséséhez vezettek. Az ezredfordulón a visszaesés üteme megállt, és a vasúti személyforgalom a XX. század végén 153-155 millió utasfő/év volt.

1. táblázat. A MÁV Zrt. személyszállítási adata (1970-2002) (millió fö/év)

\begin{tabular}{c|c|c|c|c|c|c|c|c|c}
\hline & $\mathbf{1 9 7 0}$ & $\mathbf{1 9 8 0}$ & $\mathbf{1 9 8 5}$ & $\mathbf{1 9 9 0}$ & $\mathbf{1 9 9 2}$ & $\mathbf{1 9 9 4}$ & $\mathbf{1 9 9 6}$ & $\mathbf{2 0 0 0}$ & $\mathbf{2 0 0 2}$ \\
\hline $\begin{array}{c}\text { Elszállított } \\
\text { utasfö }\end{array}$ & 346,6 & 245,8 & 204,1 & 208,2 & 171,5 & 155,8 & 153,3 & 154,2 & 162,1 \\
\hline \multicolumn{6}{c|}{ Forrás: VKI (2005) }
\end{tabular}

Az elmúlt évtizedekben végbement változások (például: motorizáció és a közlekedés fejlődése, az utazási szokások és igények változása, digitalizáció, környezetvédelem stb.) éreztetik környezeti hatásukat, melyre a vasútnak is reagálnia szükséges.

A MÁV-csoport Magyarország legnagyobb, legfontosabb kötöttpályás közlekedési szolgáltatója. A cégcsoport feladati közé tartozik a pályahálózat üzemeltetés, a személyszállítás, vontatás, karbantartás, járműgyártás. 2007. július 1-én alakult meg a személyszállító leányvállalat, a MÁV-START Zrt. 2014-ben összevonásra került a szintén 2007-ben kialakított MÁV-Gépészet Zrt és MÁV-Trakció Zrt és a MÁV-START Zrt. Az új társaság neve MÁV-START Zrt. lett, a vontatás és gépészeti képességet is magába integrált vállalatként múködik. A MÁV-START Zrt. az egyetlen európai vasúttársaság, amelyik saját járműgyártási képességgel rendelkezik! A Magyar Állammal 2023. december 31-ig érvényes közszolgáltatási szerződése van.

A MÁV-START Zrt. a hazai 7.273 km-es vasúthálózaton összesen 1.344 ponton (pályaudvar, vasútállomás, megállóhely) szolgálja ki az utasokat, napi több ezer járattal. A vállalat szolgáltatási tevékenységét 1.863 személykocsi, 467 motorkocsi, 976 (dízel/villamos) mozdony segítségével látja el. A vállalat az egyik legnagyobb hazai foglalkoztató, jelenleg több, mint 14.000 munkavállaló végzi mindennapi, felelősségteljes feladatként az utasok kiszolgálását.

\section{A MÁV-START Zrt. szolgáltatásfejlesztése}

Jelenleg a tömegközlekedés aránya nemzetközi összehasonlításban még kedvezőnek mondható, de a rendszerváltozást követô évtizedekben a társadalmi, gazdasági folyamatok, valamint a rendszeresen elmaradó infrastruktúrafejlesztés miatt a magyar vasút utasforgalma folyamatosan csökkent és folyamatos piacvesztés következett be. 
Még a relatív legsikeresebb Budapest elővárosi forgalomban is jelentős visszaesés következett be, mely megfigyelhető abban is, hogy a Budapest agglomerációjából a fővárosba ingázók alig 15\%-a veszi igénybe a vasút szolgáltatásait. Az elmúlt évek csökkenő utasszám tendenciája 2017-ben megfordult. Ennek köszönhetően meghaladta a 140 milliós utasföt.

A MÁV-START Zrt és a MÁV csoport a felügyeleti szervekkel, minisztériumokkal együttmúködve a szolgáltatási stratégia három pilléren nyugvó fejlesztésébe kezdett. Ennek mentén valósultak meg az elmúlt évek fejlesztései.

A fejlesztési stratégia három pillére:

1. Menetrendi fejlesztés

2. Jármúfejlesztés

3. Értékesítésfejlesztés

A következőkben a jármű- és értékesítésfejlesztés főbb eredményeivel szeretnék részletesebben foglalkozni.

\section{Jármüfejlesztés}

Az elmúlt évtizedek elmaradt járműfejlesztései sajnos nyomot hagytak a MÁV-STRAT Zrt. járműflottáján. A vasúti kocsik jelentős része jócskán elöregedett, az 1.863 kocsi átlagéletkora több mint 37 év. A vállalat az idősebb járműveken való korszerűsítő ráncfelvarrások mellett új járművek beszerzésével is próbálja az utasok kényelmét növelni.

A legsikeresebb ilyen beszerzés a svájci gyártmányú FLIRT motorvonatok beszerzése volt, amely során 102 db jármúvet állítottak forgalomba, főleg a budapesti elôvárosi forgalomban (1. ábra).

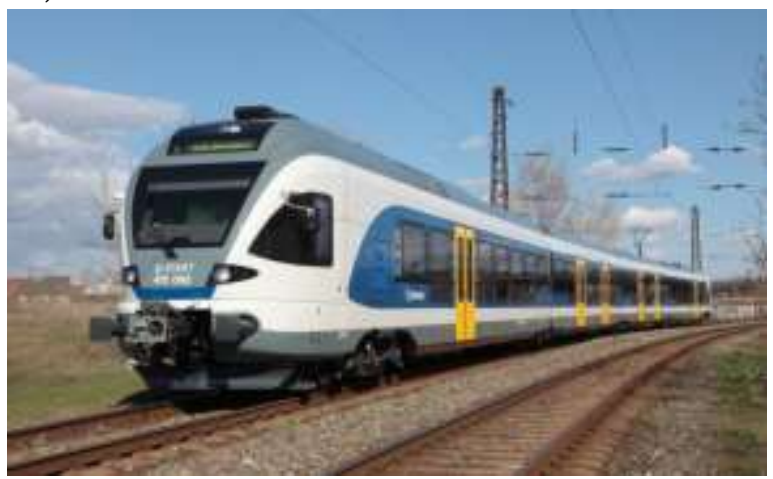

1. ábra. FLIRT motorvonat

Forrás: MÁV-START Zrt belsô anyaga

A következő lépésben 2020. év elejétől állnak forgalomba a 600 fő befogadóképességű, nagykapacitású, emeletes KISS motorvonatok. Ezeknek kell kiszolgálni a legforgalmasabb elővárosi vonalakat: Vác-Budapest és Szolnok-Cegléd-Budapest viszonylatokban (2. ábra). 


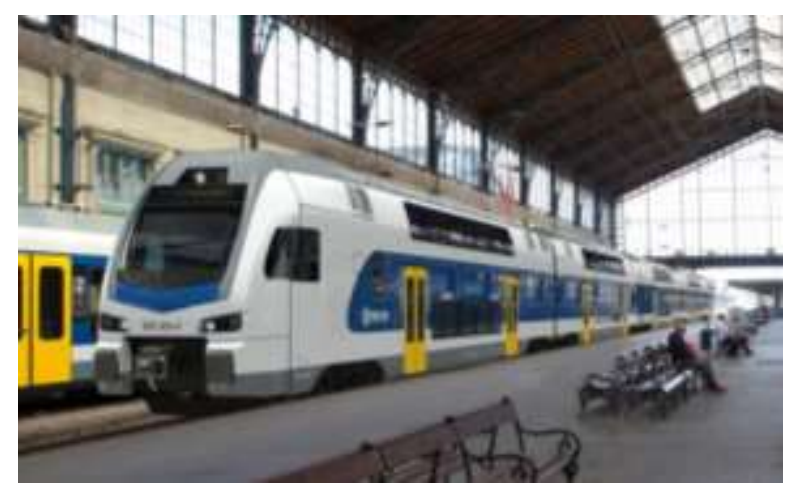

2. ábra. KISS motorvonat

Forrás: MÁV-START Zrt. belsố anyaga

Szintén a svájci Stadler cég szállítja a Szeged-Hódmezővásárhely között közlekedő TramTrain hibrid jellegű járműveket, amelyek a városokon belül villamosként, városok között pedig vonatként fognak közlekedni. A járművek a vasúti pályaszakaszon $100 \mathrm{~km} / \mathrm{h}-\mathrm{s}$, a városi szakaszon $50 \mathrm{~km} / \mathrm{h}$-s közlekedési sebességre lesznek alkalmasak. A komplett megoldáshoz új szemléletű tarifamegközelítés szükséges, például kombinált jegytermékekkel, helyközi tarifával stb. A pályahasználati feltételek kidolgozás alatt vannak.

A MÁV-START Zrt. saját berkein beül is végez járműfejlesztési tevékenységet. A Járműfejlesztési Igazgatóságon elkészült tervek alapján jelenleg is folyik $95 \mathrm{db} \mathrm{IC}+$ jármű (2. osztály, többcélú teres jármű, 1. osztályú kocsi) gyártása, melyek jelentős mértékben segíteni fogják a vállalat hazai IC és a nemzetközi forgalmát.

A budapesti agglomeráció közlekedésében 11 darab a fôvárosba befutó vasútvonal vesz részt. Ezek nagyobb része a távolsági és nemzetközi közlekedésben is meghatározó szerepet játszó, nagy teljesítményű, többségében kétvágányú villamosított fővonal (3. ábra). 


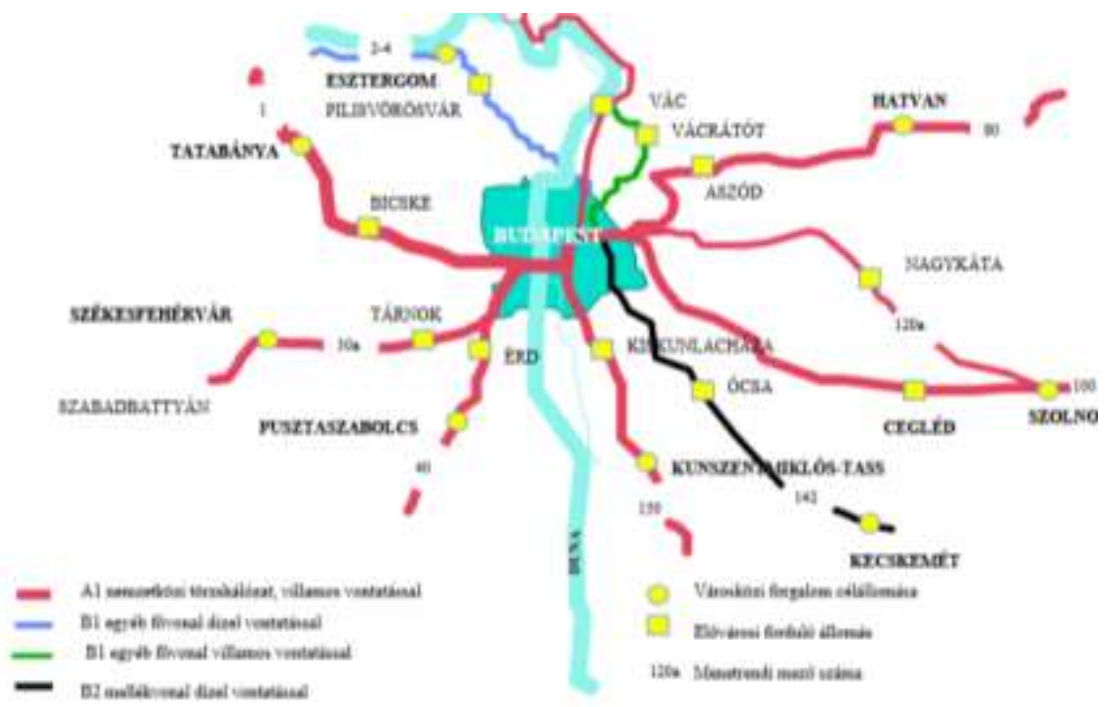

3. ábra. A budapesti agglomeráció vasúti közlekedése

Forrás: VKI (2005)

Budapest elővárosi közlekedésében is folyamatos, komplex szolgáltatásfejlesztést hajt végre a vállalat, melynek főbb elemei az alábbiak:

- Pályakorszerűsítés

- Állomások felújítása

- Modern motorvonatok beszerzése

- Attraktív menetrend bevezetése

A teljesség igénye nélkül Budapest agglomerációs közlekedésében az alábbi fejlesztések zárultak sikeresen a közelmúltban:

- 2-es vonal: Óbuda-Esztergom szakasz teljes felújítása, melybe beletartozott a pálya, a mútárgyak, kapcsolódó utak, állomásépületek, peronok, biztosítóberendezés, utastájékoztatás felújítása, $\mathrm{P}+\mathrm{R}$ parkoló kialakítása. A pálya felújítása és egyes szakaszokon új nyomvonal kijelölése, valamint szakaszosan kétvágányú pálya kiépítése mind a kapacitás növelését, mind a zavarérzékenység csökkentését szolgálták.

- 30a vonal: Kelenföld-Tárnok szakasz komplex átépítése, mely során második vágány építése, sebességemelés, tengelyterhelés-növelés, állomásfelújítás, központi forgalomirányítás kiépítése történt meg. Főbb eredmények: sűrűbb menetrend és rövidebb eljutási idők.

A fenti két vonal esetén jelentős menetidő-csökkenést, illetve utasszámnövekedést mértek a vállalat szakemberei. A 30a vonal esetén a menetidő csökkenés a KelenföldSzékesfehérvár viszonylatban mintegy 20 perc volt, ez pedig kb. 14\%-os utasszám növekedést generált. Ugyanakkor a legérdekesebb adatot a Budapest-Esztergom vonal 
felújításának teljes befejezése után tapasztalták. A 20 perces menetidőcsökkenés, és az ütemes, kiszámítható menetrend bevezetése kb. 90\%-os utasszám növekedést okozott a vonalon.

A jelenlegi és legfontosabb felújítási projekt a Budapest-Gödöllő-Hatvan (80a) vonal felújítása. A 67 kilométer hosszú pálya 20 kilométeres része Budapest területén helyezkedik el (Budapest-Keleti, Kőbánya felső, Rákos, Rákosliget, Rákoscsaba, Rákoscsaba-Újtelep, új megállóhelyként Akadémiaújtelep), főként a fơváros XVII. kerületének közlekedését támogatva. A vonal további része legfőképpen Pest megye Gödöllői és Aszódi járását szolgálja ki, érintve Pécel, Isaszeg, Gödöllő, Máriabesnyő, Bag, Aszód, Hévízgyörk, Galgahévíz és Tura településeket, majd a Heves megyei Hatvant, amely az elővárosi vonal végállomása, de a távolsági vonatok innen folytatják útjukat Szolnok, Miskolc, Szerencs, valamint Nyíregyháza irányába.

A vasútvonal állaga az elmúlt több mint 30 évben jelentős mértékben leromlott, több helyen állandó lassújelek kihelyezésére és sebességkorlátozásra volt szükség a pályaállapotok miatt. A vonalszakasz az időközben meghatározott V.sz. helsinki korridor részévé lett, így kiemelten fontos szerep jut neki az elkövetkezendő időszakban.

Az egyes közlekedésfejlesztési projektekkel összefüggő közigazgatási hatósági ügyek nemzetgazdasági szempontból kiemelt jelentőségű üggyé nyilvánításáról és az eljáró hatóságok kijelöléséről szóló 345/2012. (XII.6.) Kormányrendelet alapján a RákosHatvan-Miskolc-Nyíregyháza szakasz rekonstrukciója nemzetgazdasági szempontból a kiemelt jelentôségű beruházások körébe tartozik. A vasútvonal átépítése után a pályasebesség és a pálya tengelyterhelése, teherbírása is növelhető lesz, a forgalmi irányító és biztosítóberendezéseket is kicserélik. Az állomások és megállóhelyek kialakítása magas színvonalon fogja kielégíteni a mai kor igényeit. Az állomásokon és a megállóhelyeken új távközlés, vizuális utastájékoztatás, hangosítás kerül kiépítésre. A vonalszakasz a lakóterületek felé zajvédőfallal lesz lehatárolva. A munkálatokat több szakaszra bontva végzik el. Jelenleg a legnagyobb terjedelmű, a Pécel-Aszód pályaszakasz teljes felújítása zajlik a vasúti forgalom teljes kizárásával. A kieső szerelvényeket az elővárosi forgalomban Pécel és Aszód között pótlóbuszokkal, illetve a H8-as Budapest-Gödöllő HÉV segítségével pótolják. Az Intercity forgalomban Budapest-Hatvan viszonylatban közvetlen vonatpóló buszok közlekednek.

A szolgáltatásfejlesztés azonban nem csak a budapesti agglomerációra terjed ki. Fontos szolgáltatási terület, ahol jelentős fejlődés tapasztalható, a Balaton nyári kiszolgálása, illetve a nemzetközi vonatközlekedés. A balatoni közlekedés legfőbb fejlesztései melyek már 2017-tôl megvalósultak a következők:

- a kiszámíthatóbb menetrend, sűrűbb eljutás;

- csúcsidőben mentesítô vonatok, előszezoni menetrend;

- klímás vonatok;

- IC, expresszvonatok garantált ülőhellyel;

- pontosság, a menetidő az autópályás közlekedéssel is versenyképes; 
- az északi partra új ,járatbrandek” meghonosítása, mint pl. Tekergő gyorsvonatok, Kék Hullám, Katica.

A nemzetközi forgalomban új és felújított járművek segítségével biztosítják a kényelmes utazást. Év közben a legjelentősebb viszonylatok a Budapest-Pozsony-Prága-BerlinHamburg, illetve a Budapestről Lengyelország, Ukrajna, Románia, Szerbia, Horvátország felé közlekedő járatok. A nyári időszakban célvonatokkal igyekeznek kiszolgálni az Adriai-tengerhez igyekvő nyaralók igényeit.

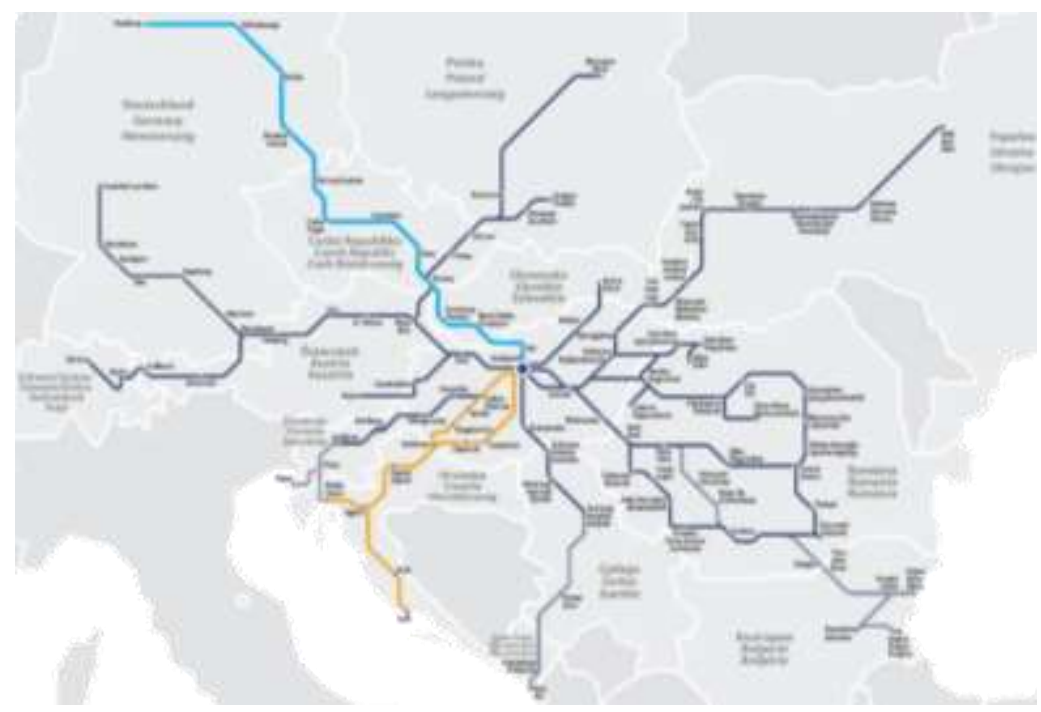

4. ábra. MÁV-START nemzetközi hálózata (2019)

Forrás: MÁV-START Zrt. belső anyaga

\section{Elektronikus jegyértékesítés kezdete (USA)}

Az Amerikai Egyesült Államok repülési forgalmának jelentős részét (közel 70\%-át) már akkor is az üzleti utasok tették ki. Az üzleti utasok eleve magasabb szintű informatikai, technológiai háttérrel rendelkeztek, így könnyebben alkalmazkodtak az új jegyfoglalási rendszerhez, mint az ún. hétköznapi utasok.

A rendszer legfőbb előnyei az utasok számára a kényelem és a biztonságosabb utazás voltak. Míg a hagyományos jegyeket az utasoknak egész utazásuk során magukkal kellett vinniük, addig a központi adatbázisban digitális formátumban tárolt e-jegy alkalmazásával a jegy elvesztésének, illetve eltulajdonításának esélye minimálisra csökkent. A jegy felhasználásának egyetlen feltétele, hogy a felhasználó hitelt érdemlően azonosítani tudja magát megfelelő igazolvány segítségével.

A hagyományos jegy fő feladata, hogy bizonyítsa a közlekedési társaság számára, hogy az utas fizetett az utazásért, dokumentálja a jegyeladást és lehetővé teszi a szabad/foglalt helyek kezelését. Az e-jegy központi adatbázison keresztül történő helyfoglalást és nyomon követést tesz lehetővé. A légitársaság számára az e-jegyek számos egyértelmű 
előnyöket biztosítanak, melyek közül a legfontosabb a papír előállítási, kezelési költségek csökkenése, a papír alapú jegy hamisítási lehetőségének megszűnése. Az elektronikus jegyek bevezetése jelentősen csökkentette az elveszett, ellopott jegyek számát, és szükségtelenné tette az előre váltott jegyek használatát.

Az e-ticketing előnyei olyan mértékűek voltak, hogy a Nemzetközi Légi Közlekedési Szövetség (IATA) 2007 decemberétől megszüntette a papírjegyek értékesítését és feldolgozását (Bisignani - Peters, 2005).

Materiális megjelenésében nagyon sok féle „okos” jegy terjedt el, de ezek igazából két fő csoportba sorolhatók be: „vonalkódos” jegyek, illetve „okos kártya” jellegú jegyek. Mindkét típus titkosítást tartalmaz, ezzel a hagyományos papír alapú jegyeknél nehezebb hamisítani őket, és ez csökkenti a jegyekkel való visszaélések esélyét. A „,vonalkódos” jegyek mindegyikén elhelyezkedik egy-egy vonalkód, amely lehetővé teszi a megfelelő elektronikus eszközzel történő olvasást és a benn foglalt tartalom megjelenítését. Ezzel szemben az „okos kártya” jellegú jegyeknél a jegy egy bankkártya méretű plasztik lapon kerül rögzítésre, lehetővé téve ezzel az érintés nélküli kiolvasást rádióhullámok segítségével.

Az informatikai rendszerek térnyerése a vasúti jegyértékesítésben is megjelent. A 2000-es évek elején a legtőkeerősebb, nagy utasforgalmat lebonyolító vasúttársaságoknál, mint például a Deutsche Bahn-nál (DB), a Schweizerische Bundesbahnen-nál (SBB), illetve a Société Nationale des Chemins de Fer Français-nál (SNCF) vezették be az elektronikus jegyértékesítést.

Az elektronikus vasúti jegy fő jellemzői nagyon hasonlítanak egy repülőjegyre. A repülőjegyekhez hasonlóan a Deutsch Bahn (DB) online jegyet is az utasok előre fizetik. Minden jegyhez egyedi számot rendelnek (utas)nyilvántartási adatlapot (PNR), és minden egyes foglaláshoz testre szabják ( $\mathrm{Ng}$-Kruelle et al., 2006).

Az elektronikus vasúti jegyek értékesítési rendszere azonban már a kezdetektől jelentős eltéréseket mutatott a repülésipari e-jegy értékesítéstől. A 2. táblázat a Deutsche Bahn példáján keresztül mutatja be a két rendszer közötti különbségeket.

Mint a 2. táblázatban is látható a legnagyobb különbségek a rendszer hozzáférhetőségében (nyitott/zárt), illetve rugalmasságában találhatók.

\section{2. táblázat. E-jegy értékesítési rendszerek összehasonlítása a légitársaságok és a vasút esetében}

\begin{tabular}{|c|c|c|}
\hline & Légitársaságok (IATA) & Deutsche Bahn \\
\hline Ülőhely foglalás & $\begin{array}{l}\text { - Kötelező } \\
\text { - Korlátozott számú ülések }\end{array}$ & $\begin{array}{l}\text { - Ajánlott, de nem szükséges } \\
\text { - A vonaton tartózkodó utasok } \\
\text { száma nem függ az ülések } \\
\text { számától, bizonyos helyzetekben } \\
\text { az utasok állhatnak is }\end{array}$ \\
\hline Ellenőrzési pont & $\begin{array}{l}\text { - Beszállás előtt } \\
\text { - Zárt nyilvános hozzáférés }\end{array}$ & $\begin{array}{l}\text { - Nem alkalmazható } \\
\text { - Nyílt nyilvános hozzáférés }\end{array}$ \\
\hline
\end{tabular}




\begin{tabular}{|c|c|c|}
\hline Jegyellenőrzés & $\begin{array}{l}\text { - } \text { Központi számítógépes } \\
\text { foglalási rendszer } \\
\text { - Online vezérlőegységek. } \\
\text { - A beszállás és az ellenőrzés } \\
\text { előtt }\end{array}$ & $\begin{array}{ll}- & \text { Decentralizált } \\
\text { - } & \text { Offline vezérlőegységek. Ezek a } \\
& \text { meglévő informatikai és fedélzeti } \\
& \text { infrastruktúrákon alapulnak } \\
\text { - } & \text { Vonatokon } \\
\end{array}$ \\
\hline $\begin{array}{l}\text { Utazási } \\
\text { rugalmasság }\end{array}$ & $\begin{array}{l}\text { - Nem rugalmas, rögzített } \\
\text { utazási terv } \\
\text { - } \quad \text { Utasok listája rögzített, így } \\
\text { papírmentes e-jegy is } \\
\text { lehetséges, csak az utasok } \\
\text { azonosságát ellenőrzik az adott } \\
\text { ellenőrzési pontokon }\end{array}$ & 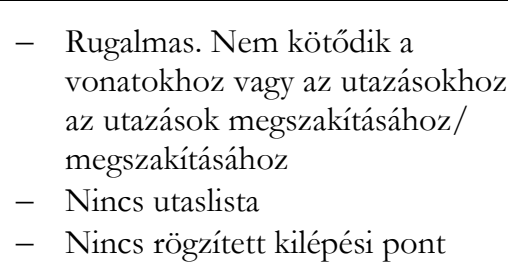 \\
\hline $\begin{array}{l}\text { Online foglalás } \\
\text { és törlés }\end{array}$ & $\begin{array}{l}\text { - } \\
\text { E-jegy } \rightarrow \text { beszállókártya } \\
\text { A megerôsítés után nem } \\
\text { lehetséges az online lemondás } \\
\text { vagy az utazási tervek } \\
\text { módosítása }\end{array}$ & $\begin{array}{ll}- & \text { E-jegy = beszállókártya } \\
- & \text { Az utazási tervek online törlése } \\
& \text { vagy módosítása a megerősített } \\
& \text { foglalások után is lehetséges }\end{array}$ \\
\hline
\end{tabular}

\section{Elektronikus jegyértékesítés a MÁV-START Zrt.-nél}

Az elmúlt években a MÁV-START Zrt. jegyértékesítése jelentős fejlődésen ment keresztül. Az 1970-es évek papíralapú vasúti jegyét az 5. ábra szemlélteti.

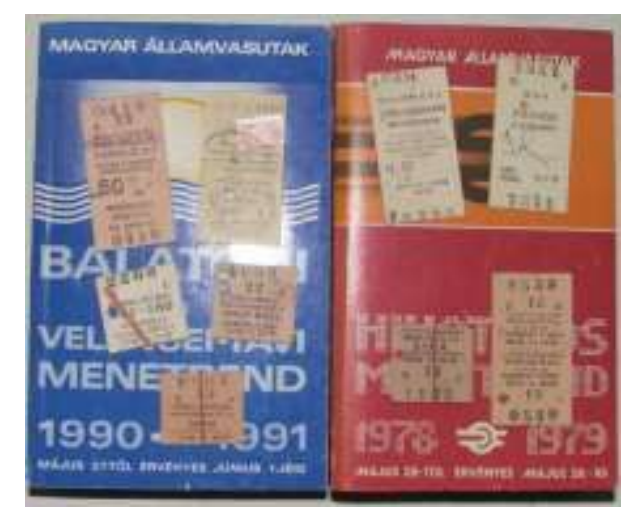

\section{5. ábra. Papíralapú vasúti jegyek az 1970-es években}

Forrás: Hovamegyavonat, 2013

Ma már nem szükséges elmennünk egy jegypénztárhoz, hogy személyesen, hosszas sorban állás után vegyük meg a menetjegyet. A korábban csak a jegypénztárakban elérhető funkciók jelentős része ma már elérhető alternatív útvonalakon is. Ezek közül a legjellemzőbbek:

- a jegyautomatás vásárlás,

- az internetes felületen, illetve

- a Vonatinfo (2019-tôl MÁV) alkalmazáson keresztül történő jegyértékesítés. 
Az elektronikus jegyértékesítés a nemzetközi trendeket követve 2011 végén indult el. Kezdetben a minőségi távolsági vonatokon (IC, EC, EN, Expressz) volt lehetséges a jegyek interneten történő megvásárlása, otthoni nyomtatása vagy elektronikus bemutatása (6. ábra). A gyorsvonati pótjegyek bevezetés után a sebes és gyorsvonatokra is kiterjesztették az elektronikus bemutatás lehetőségét.

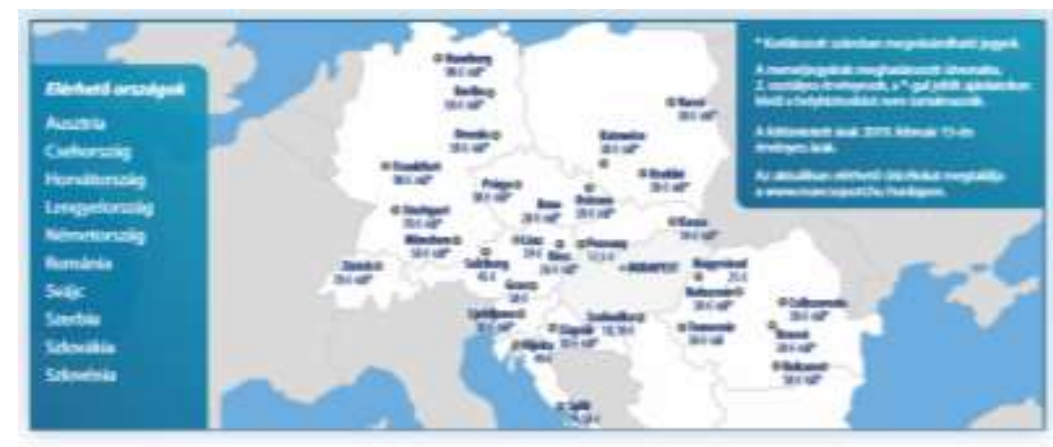

6. ábra. A legnépszerűbb úticélok, ahová interneten is váltható jegy (2019) Forrás: MÁV-START Zrt. belsó anyaga

A legnagyobb áttörés 2016 novemberében jött le, amikor a MÁV-START Zrt. valamennyi személyszállító járatán bemutathatóvá vált a pdf alapú elektronikus vonatjegy, amelynek neve innentől e-vonatjegy lett. 2017 februárjától kísérleti jelleggel bevezették, hogy a Budapest-Pusztaszabolcs vonalra érvényes bérletek már az új, elektronikus személyi igazolványra is feltölthetők.

Az értékesítés másik fontos színtere a jegykiadó automaták, melyek országszerte egyre elterjedtebbek, és a jegyvásárláson kívül lehetővé teszik menetrendi információk megjelenítését, illetve interneten vásárolt jegyek átvételét is. A 7. ábrán látható a jegykiadó automaták országos elhelyezkedése. 


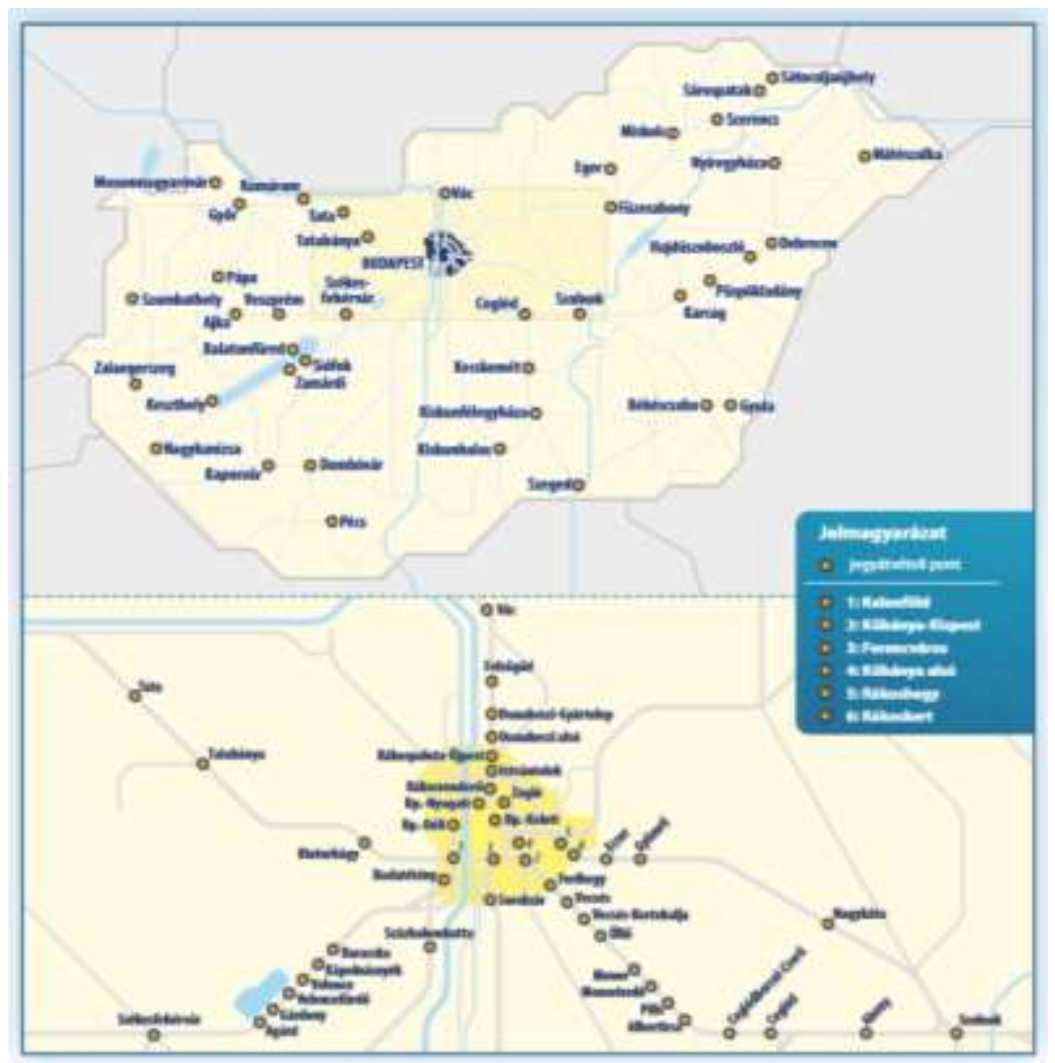

7. ábra. MÁV-START Zrt. jegyátvételi pontok (2019)

Forrás: MÁV-START Zrt. belső anyaga

A jegyértékesítő automaták használatával bármilyen belföldi viszonylatra vásárolhatók menetjegyek, bérletek, pót- és helyjegyek, kerékpárjegyek, illetve élóállat jegyek. Az új automaták egyesítik a jelenlegi jegykiadó és az internetes jegynyomtató automaták feladatkörét, hiszen az azonnali jegyvásárláson túl az előzetesen, interneten vásárolt jegyek átvétele, kinyomtatása is lehetséges. Az automatáknál a nap 24 órájában készpénzzel és bankkártyával is lehet fizetni, továbbá lehetőség van az érintkezésmentes bankkártyák használatára is.

A fejlesztéssel a budapesti elővárosban egyszerűsödik az utasok jegyhez jutási lehetősége olyan állomásokon és megállóhelyeken, ahol eddig nem volt jegyvásárlási lehetőség, illetve csökken a sorban állásra fordított idő ott, ahol eddig is volt jegypénztár.

A legújabb és legdinamikusabban fejlődő értékesítési csatorna a Vonatinfo (2019-től MÁV) alkalmazás, amelyhez kapcsolódóan az elmúlt egy évben közel 2,5 millió vásárlási tranzakció történt, összesen megközelítőleg 1,2 milliárd forint értékben. A jegyvásárlás mellett menetrendi keresővel, térképes vonatkövető rendszerrel is rendelkezik. A Vonatinfó nevű menetrendi és térképes utastájékoztatási alkalmazás indulása és az evonatjegyek bevezetése óta nagy volt az igény az utasok részéről, hogy a mobiltelefonos 
applikációban is lehessen jegyet vásárolni. A MÁV-START ezért bővítette ki a jegyvásárlási funkcióval az igen népszerű, 400 ezer letöltést elért mobilalkalmazását. A frissített alkalmazás korábbi, ún. bétateszt verzióját korlátozott számú (mintegy ezer) felhasználó próbálhatta ki androidos operációs rendszerű mobiltelefonokon. A sikeres tesztelés után, a Google Play áruházon keresztül, a Google fokozatosan bővülő számú felhasználó részére kínálta fel a jegyértékesítést is tartalmazó frissítés lehetőségét, ami július közepére ért el az összes androidos felhasználóhoz. Azóta mintegy 131 ezer androidos telefonon frissítették az applikációt és több mint nyolcezren regisztráltak az értékesítési felületen. Ők már csaknem 40.000 vasúti jegyet vettek néhány kattintással a mobiljuk segítségével. 2018. július 23-tól az iOS operációs rendszert használó telefonokra is letölthető a frissítés az AppStore-ból. Ma már minden Android és iOS operációs rendszerrel működő okostelefonra letölthető és korlátlanul igénybe vehető. Bár a vasúttársaság a dijmentesen letölthető Vonatinfo applikációt helyezi előtérbe az internetes jegyvásárlásra, az utasok 95,5 százalékban még nem ezzel veszik meg a vonatjegyeiket.

Az utasok a mobiltelefonjukon vehetik meg a MÁV-START és a GYSEV (Győr-SopronEbenfurt-i Vasút) szolgáltatási területére érvényes belföldi, egy útra szóló menetjegyüket és a hozzá kapcsolódó felárakat, pót- és helyjegyeket, valamint a kerékpár- és kutyajegyet (élőállat jegyet). A Vonatinfóba letöltődő jegyeiket is mobiltelefonon tudják bemutatni, akár offline, azaz internet elérés nélkül is. A felhasználók utazási és jegyvásárlási szokásaihoz igazodva az új Vonatinfó gyors és egyszerű jegyvásárlást biztosít az utasoknak azáltal, hogy a korábban létrehozott utazási beállításokat és az utazók adatait megjegyzi az alkalmazás. Nemcsak a kényelmes használat, vagy a sorbaállás elkerülése miatt érdemes mobiltelefonon vonatjegyet venni, az alkalmazásból 10\%-os kedvezménnyel vásárolhatók e-vonatjegyek, és a jelölt vonatokra igénybe vehető 20\%-os árengedmény.

A Vonatinfón vásárolt vonatjegyek felhasználási feltételei megegyeznek az evonatjegyével: személyhez kötöttek, nem ruházhatók át másra, és legkésőbb az érvényességkezdete előtti 1 órán belül válthatók vissza az alkalmazáson keresztül. A visszaváltott vagy lejárt érvényességú jegy már nem használható utazásra. Bérletet azonban még nem lehet vásárolni a Vonatinfó applikációval. A Vonatinfó alkalmazás korábbi kedvelt funkciói (menetrendi és vonatinformációk, vonatkövetés, térkép) továbbra is múködnek regisztráció nélkül, azonban a jegyvásárláshoz regisztráció szükséges. Az alkalmazás által biztosított rugalmasságot az első használatot követően tudják majd a felhasználók igazán kihasználni, ugyanis az első vásárlás alkalmával végig kell menni a kötelező regisztrációs lépéseken: pl. felhasználói adatok megadása, elektronikus számlaadatbeállítása, esetleg bankkártya adatok eltárolása. A későbbi vásárlások során ezek az adatok előhívhatók és felhasználhatók, de belépés után módosítható is minden előzetesen mentett adat.

Új elem a vonatinfós alkalmazásban, hogy több utast (pl. családtagokat) és azok kedvezményeit, korosztályát lehet regisztrálni, így közös, például családi utazás esetén is 
használható az alkalmazás jegyvásárlásra, ráadásul egy későbbi utazás alkalmával már csak ki kell választani azok nevét, akiknek jegyet kívánnak venni. Fontos tudni, hogy a jegyek csak abból a felhasználói profilból érhetők el, amiből azokat vásárolták, mások részére nem lehet a jegyeket átküldeni.

A már több éve működő internetes jegyvásárlási rendszer és a Vonatinfó nem átjárható, vagyis az internetes jegyértékesítési rendszerben élő regisztráció nem használható a Vonatinfó applikációban, és az interneten vásárolt jegy sem tölthető le a Vonatinfóba, illetve fordítva sem múködik. Ennek oka, hogy a Vonatinfó alkalmazás már a pénztárakban és a vonatok fedélzetén is használt új jegyértékesítési rendszeren alapul.

A bankkártyás fizetés a SimplePay online fizetési rendszerében történik (ahol a fizetési információk elmenthetők a későbbi vásárlásokhoz), majd a megvásárolt jegy letöltődik az applikációba. A jegyvásárlással egyidejűleg elektronikus számlát kap az utas a regisztrált email címére. Utólagos számlaigényt nem lehet benyújtani, és a kiadott számla sem módosítható.

A jegyvásárláshoz aktív internetkapcsolat szükséges, azonban a korábban vásárolt jegyek térerő vagy mobil-adatforgalom hiányában is elérhetők és bemutathatók a vonaton az ellenőrzésnél. Egy applikációban egyidejűleg több utas (pl. gyermek, házastárs, nagyszülő, barát) részére is tárolható jegy. Minden megvásárolt jegyen külön szerepel az azt felhasználó utas neve, és csak az az utas használhatja fel, akinek személyazonosító adatait a vásárlási felületen megadták. A jegyellenőrzéskor minden esetben fel kell mutatni a személyazonosításra alkalmasokmányt is.

A Vonatinfóval vásárolt jegy csak az érvénytartam kezdetét megelőzően, a vásárlási felületen közzétett feltételek szerint, és csak az applikáción keresztül téríthető vissza. Pénztári visszatérítés nem lehetséges. Különleges esetekben és a vasúttársaság hibájából szükségessé vált visszatérítés esetén a MÁV-START ügyfélszolgálatához kell fordulni. Az online visszatérítésesetén a kezelési költség mértéke kedvezőbb az üzletszabályzatban előírtaktól: a menetjegy és a gyorsvonati pótjegy esetén a visszatérítendő menetdíj 10\%a. Más felár esetén a vonat indulása előtt legkésőbb 24 órával kezdeményezett visszatérítésnél nincs kezelési költség; ha már nincs 24 óra a vonat indulásáig, de ha a visszatérítést a vonat indulása előtt legkésőbb 1 órával kezdeményezik, akkor a visszatérítendő pót- és/vagy helyjegyek árának 10\%-a kezelési költségként levonásra kerül.

Az adatok védelme érdekében az érzékeny, személyes adatokat nem a telefonkészüléken tárolja a program. A MÁV-START a Vonatinfó rendszerből nem ismer meg, és nem tárol semmilyen banki adatot, azokat továbbra is csak a fizetési szolgáltató kezeli.

A Vonatinfó a közeljövőben bérletváltási funkcióval is bővülni fog, de az internetes felület is megújul, és egy, a pénztárakkal megegyező funkciójú, önkiszolgáló értékesítési csatorna nyílik meg a vásárlók előtt. A pénztári, elektronikus személyi igazolványhoz kötött bérletértékesítés, majd jegyértékesítés országos kiterjesztésével körülbelül egyidőben a Vonatinfó alkalmazás is kibővül annak érdekében, hogyha a felhasználó rendelkezik elektronikus személyi igazolvánnyal, és azt használja, mint bérletigazolvány, 
akkor dönthessen úgy, hogy csak és kizárólag az elektronikus személyi igazolványát használja az utazási jogosultság igazolására.

Az új értékesítési csatornák közös jellemzője, hogy a szolgáltató kedvezményeket nyújt a szolgáltatást igénybe vevőknek. Ez a kedvezmény változó, a szolgáltató az automatákból vásárolt jegyekre 5\%, az e-vonatjegyekre 10\%-os kedvezményt nyújt, és egyes csúcsidőn kívüli, legalább százkilométeres utazásokra akár 20\%-os kedvezmény is elérhetô.

A tavalyi évben sokéves csúcsot döntött a vasúti közlekedés. A MÁV 2018-ban átlépte a 70 milliós darabszámot az eladott belföldi jegyek kategóriájában. Ezenkívül a becslések szerint csaknem 790 ezer nemzetközi utazási engedélyt is értékesítettek, így a tavalyi összes jegyeladás megközelítette a 72 millió darabot. A statisztika értelmezésekor fontos tisztában lenni azzal, hogy a megvásárolt jegyek száma nem azonos a MÁV szolgáltatását igénybe vevő utazóközönség számával, tehát nem annyi ember utazott vasúton, mint ahány jegyet értékesítettek. Ez ugyanis egy összesítő adat, amely tartalmazza például a bérleteket és a pót- és helyjegyeket is. Nem foglalja magában azok jegyeit, akik a vonatkozó jogszabály alapján dijmentesen utaznak - 65 év felettiek, hat év alattiak, határon túli magyarok, díjmentesen utazó diákcsoport stb. -, és a gyűjtés a fơváros közigazgatási határain belül Budapest-bérlettel közlekedőket sem veszi figyelembe.

A jegyeladások és az utasszám között szoros összefüggés van, az előbbi növekvő trendje az utóbbi bővülésére is enged következtetni.

2017. december 8-tól január 7-ig 42\%-kal többen váltották meg online a vasúti jegyet, mint az egy évvel ezelőtti azonos időszakban. A jegykiadó automaták forgalma is emelkedett, azokból 12 százalékkal többen vásároltak jegyet. Az új kedvezmények hatása már jól érzékelhető az önkiszolgáló csatornák népszerűségének növekedése. Míg 2017. november végéig az értékesített jegyek 8 százalékát vásárolták meg interneten keresztül és 13 százalékát automatákból, a bevezetés utáni első hónapban ezek az arányok 12, illetve 14 százalékra nőttek.

Az önkiszolgáló csatornákon keresztül 2018. január elsejétől 2018. szeptember 2-ig vásárolt e-vasúti menetjegyekre az utasoknak nyújtott kedvezmények összértéke meghaladta az 580 millió forintot. A 2017. decemberi menetrendváltáskor bevezetett 5, 10, 20 százalékos kedvezmények ugyanakkor jelentős, 275 millió forintos többletet eredményeztek a MÁV-START menetdíjból származó árbevételében.

A MÁV START Zrt. belső anyagai alapján a jegyértékesítés megoszlása folyamatosan az alternatív módozatok felé tolódik el. A 8. és 9. ábrán látható a 2017-es és 2018-as év jegyeladásainak adatai, melyek jól szemléltetik ezt az eltolódást az elektronikus, modern jegyvásárlási módozatok felé. 


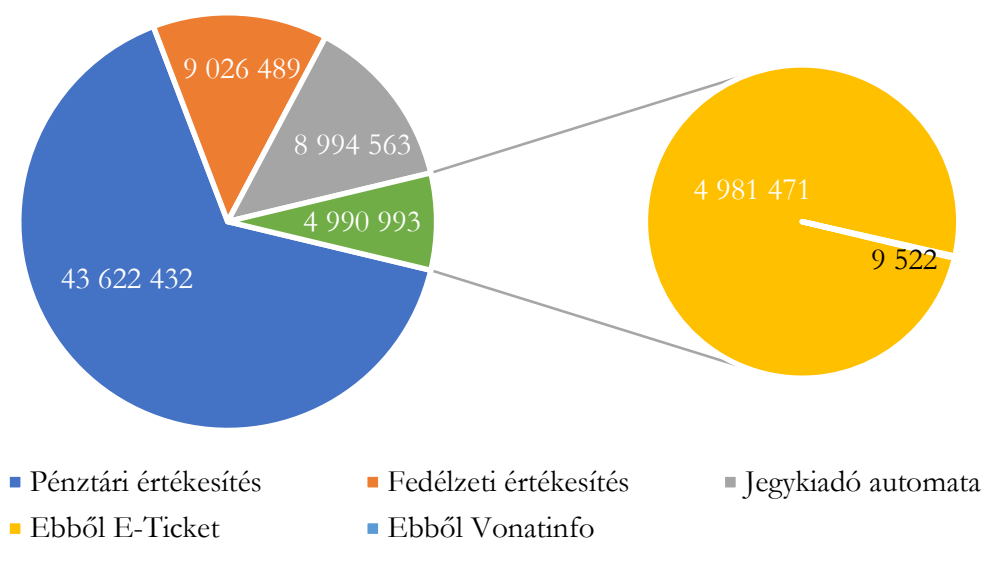

8. ábra. MÁV-START Zrt. jegyértékesítési adatai 2017-ben (db) Forrás: MÁV-START Zrt. belsố anyaga

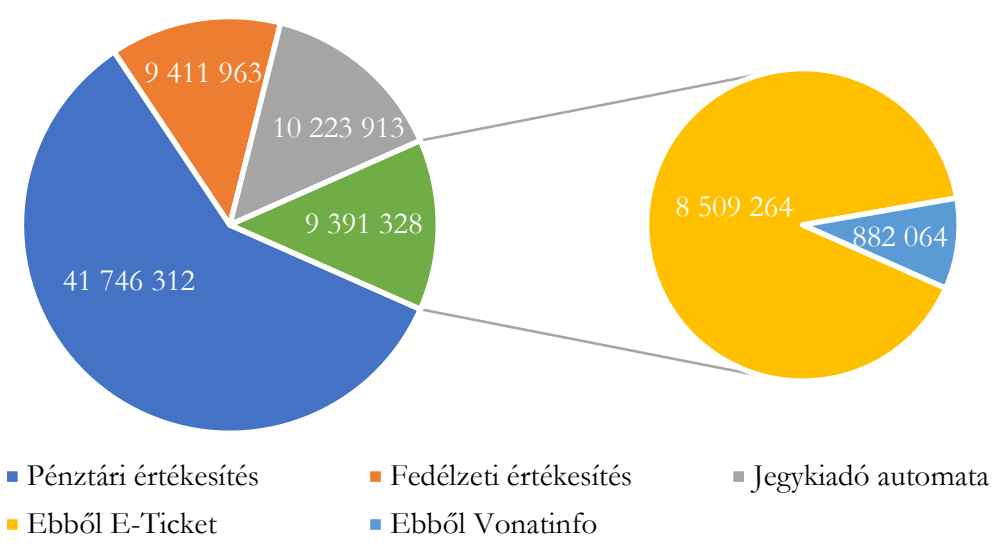

9. ábra. MÁV-START Zrt. jegyértékesítési adatai 2018-ban (db) Forrás: MÁV-START Zrt. belső információ (2019)

Az 8. és 9. ábrák értelmezéséhez fontos megjegyezni, hogy a bal oldali diagramokon a színek jelentése a következő:

- Kék: Pénztári értékesítés

- Piros: Fedélzeti (járműveken történő) értékesítés

- Szürke: Jegykiadó automatán keresztül történő értékesítés

- Zöld: Internetes jegyeladás

Ez utóbbi értékesítési adatok kerülnek megbontásra a jobb oldali diagramokon, ahol a sárga szín a „hagyományos” internetes értékesítést, míg a világoskék szín a Vonatinfo (MÁV) applikáción keresztül történő jegy értékesítési adatokat jeleníti meg. 
A jegyértékesítési adatokból megállapítható, hogy a vállalat jegyeladásai a vizsgált két évben is jelentős növekedést mutatnak, a $6 \%$ jegyértékesítés bővülés jelentősnek mondható a közösségi közlekedésben.

Ha részletesen megvizsgáljuk az egyes értékesítési módokat látható, hogy a hagyományos értékesítés 65\%-ról 59\%-ra csökkent, míg az alternatív vásárlási módok aránya folyamatosan növekszik. A jegyértékesítő automatából történő vásárlások száma közel 1,5 millió darabbal emelkedett. Ez az összes értékesített jegy 14,5\%-a. A vizsgált időszakban a legnagyobb arányú növekedést az internetes vásárlások adják. A 2017-es 4,99 millió eladáshoz képest 2018-ban már 9,39 millió darab jegyet adtak el internetes értékesítési felületeken. Ebbe a kategóriába mind az internetes oldalon, mind a Vonatinfo alkalmazáson keresztül történő vásárlások beletartoznak. A legnagyobb százalékos bővülés ezen a területen történt. A Vonatinfo alkalmazáson keresztül vásárolt jegyek száma a közel 10 ezer vásárlásról 880 ezer fölé nőtt, több mint 920\%-os bővülést létrehozva!

\section{KÖVETKEZTETÉSEK, JAVASLATOK}

A vasút piaci részesedésének megőrzése és növelése a közlekedésben csak minőségi szolgáltatás megvalósítása esetén várható. Ennek legfőbb ismérvei: megfelelő járatsűrűség, ütemes menetrend, pontosság, korszerű, tiszta, kényelmes járműpark, biztonságos fel- és leszállási körülmények, intermodalitás kis gyaloglási távolságokkal, az állomásokon komplex szolgáltatás, $\mathrm{P}+\mathrm{R}, \mathrm{B}+\mathrm{R}$ lehetőség, ráhordó forgalom megoldása, jegyértékesítési csatornák fejlesztése.

A szolgáltatási színvonal fejlesztése az egyik legfontosabb célkitűzése a vasútvállalatnak. $\mathrm{Az}$ infrastrukturális és járműfejlesztések mellett ezért jelent meg a jegyértékesítési csatornák fejlesztése is. A hagyományos értékesítési módokkal a mai X, Y, Z generáció számára, amelynél az okostelefon, laptop használata szinte létszükséglet, szinte nem lehet növelni a szolgáltatás igénybevételét. Ezért fontos, hogy megfelelő színvonalú, üzembiztos, megbízható jegyértékesítő rendszer álljon rendelkezésre számukra.

Különösen fontos ez a fejlesztés a főváros agglomerációjában, ahol naponta több 10 ezer ember veszi igénybe utazása során a vasúttársaság szolgáltatásait.

Az itt élők, és utazók igényeinek kielégítését szolgálják az elővárosi vasútvonalak szinte minden megállójában, állomásán elhelyezett jegyértékesítő automaták, melynek száma az elmúlt pár évben jelentősen megnőtt, jelenleg mintegy 400 darabra tehető.

Vizsgálatom kezdetén a rendelkezésemre álló adatokból megpróbáltam következtetéseket levonni a jegyértékesítés regionális mutatóira is, de sajnos a rendelkezésre álló adatokból nem tudtam ilyen mélységû adatcsoportot kinyerni.

A vizsgálataim alapján annyit tudtam megállapítani, hogy a budapesti agglomerációban jelentős mértékű az elektronikus jegyek eladása mind automatákból, mind interneten.

A MÁV-START Zrt. célja, hogy tovább erősítse az önkiszolgáló jegyértékesítési csatornákat, így állandó kedvezményekkel ösztönzi ezen csatornák használatát. 2017-ről 
2018-ra csaknem négymillióval ugrott meg a MÁV által eladott jegyek száma, a belföldi értékesítés 2018-ban lépte át először a hetvenmilliós küszöböt.

Az e-vonatjegy névre szóló, át nem ruházható, viszonylati menetjegy. Az e-vonatjegy a rajta feltüntetett időszakban érvényes, a rajta feltüntetett érvénytartamon és viszonylaton belül bármely olyan vonaton érvényesen felhasználható, melynek igénybe vehetősége az e-vonatjegyrôl világosanmegállapítható (pl. feláras vonatra érvényes felárat megfizették). Ha az e-vonatjegy helyjegyet, pót- és helyjegyet tartalmaz, a helyjegy, pót- és helyjegy csak az ottfeltüntetett vonaton érvényes. A vonathoz kötött kedvezménnyel vásárolt evonatjegy csak a jegyen feltüntetett vonat(ok)on érvényes. Az e-vonatjegy visszatérítése kizárólag a webes felületen kezdeményezhető, legkésőbb az érvényesség megkezdése előtt 1 órával.

Az e-vonatjegyet tartalmazó pdf fájlt jegyellenőrzéskor fel lehet mutatni arra:

- alkalmas készülék (pl. okostelefon, hordozható számítógép) képernyőjén, ha a készülék képes a QR-kódot legalább 160x160 képpont méretben megjeleníteni;

- A/4-es fehér papírra, méretváltoztatás nélkül jó minőségben kinyomtatva.

E-vonatjegy vásárlása esetén 10\% kedvezményt kap a vásárló a kosár végösszegéből a pénztárban történő vásárláshoz képest. Egyes járatokon 100 km-nél hosszabb távolságra a pénztári árhoz képest 20\% kedvezménnyel vásárolható e-vonatjegy. Ezek a jegyek csak a rajtuk feltüntetett vonatokon érvényesek.

E-vonatjegyet mindössze néhány egyszerű lépésben lehet vásárolni. Ezzel a módszerrel a vonat indulása előtti utolsó percig lehet megvásárolni a jegyet, de a vonat indulásának percében már nem.

Az utasok körében egyre nagyobb népszerűségnek örvend az online vásárlás, és ezen belül az e-vonatjegy. Nagy előrelépés az e-vonatjegy esetében a jegyvásárlási funkció megjelenése az igen népszerű Vonatinfó új mobiltelefonos alkalmazásban.

A legfrissebb statisztikai adatok szerint növekszik az alternatív (automata, internet, Vonatinfo) módon értékesített jegyek, bérletek száma. Az internetes jegyvásárlási rendszerben 10-ból 9 esetben az e-vonatjegyet választják az utasok, akik felfedezték és megszerették a kényelmes és gyors mobilapplikációs jegyvásárlást is, mivel a Vonatinfó használatával időt lehet megspórolni a pénztárak előtti sorban állás elkerülésével.

Az e-vonatjegy népszerűsége a gyorsaság és a kényelem mellett az utasoknak adott kedvezményeknek is köszönhető, ezek összértéke megközelítette a 70 millió forintot ebben az időszakban. A mobilalkalmazáson keresztüli jegyvásárlásokra adott 10, illetve 20 százalékos kedvezmények, illetve az önkiszolgáló csatornákon (jegyautomata, online vagy vonatinfós jegy) keresztül történő vásárlásokra nyújtott kedvezmények bevezetése óta a MÁV START Zrt adatai szerint az utasok eddig 995 millió forintot takaríthattak meg.

A vasúttársaság célja a jelentős árkedvezménnyel, hogy még vonzóbbá tegye a kényelmes és modern jegyvásárlási megoldásokat, csökkentve ezzel a pénztárak leterheltségét, és újabb utasokat győzzön meg arról, hogy érdemes a vasutat választani. Ma már a jegyek és 
bérletek kevesebb, mint 60\%-át értékesítik jegypénztárakban. Az ötödével olcsóbb csúcsidőn kívüli vonatokra átülőknek köszönhetően pedig a vasúti járatok kihasználtsága is javul.

A vasúttársaság közép és hosszútávú célja, hogy a hagyományos jegyérékesítési módok használata csökkenjen, ezzel együtt a modern, kényelmes és olcsóbb vásárlási módok aránya tovább nőjön.

Az információtechnológia gyors fejlődése és az okostelefonok szélesebb körű elterjedése miatt az elektronikus, önkiszolgáló csatornákon keresztüli vonatjegy-értékesítés tartós növekedésére lehet számítani. A turisztikai célú utazások (pénztárak előtti sorban állás helyett) is segítik az e-vonatjegy további elterjedését.

\section{FELHASZNÁLT IRODALOM}

Bisignani, G. - Peters, J. (2005): Change is in the air. Economists, pp. 19-21.

MÁV-START Zrt. belső anyagai (2019)

Hovamegyavonat (2013): A belföldi vasúti felárak legújabbkori története, 1. rész. https://hovamegyavonat.blog.hu/2013/03/12/a belfoldi vasuti felarak legujabbkori tortenet e 1 resz $(2019.07 .03$.)

Ng-Kruelle, G. - Swatman, P.A. - Kruelle, O. (2006): e-Ticketing Strategy and Implementation in an Open Access System: The case of Deutsche Bahn. https://www.researchgate.net/publication/228883725 (2019. 07. 03.)

VKI (2005): A különböző vasúti hálózatok vonali és hálózati hatékonysága, illetve a versenyképesség értelmezése a vasútnál hazai tapasztalatok és nemzetközi példák alapján. p. 66. http://www.vki.hu/ tfleisch/ haver/szakirodalom/haver-KOLLER-vasut.pdf (2019. 07. 03.)

345/2012.(XII.6.) Korm.rendelet: egyes közlekedésfejlesztési projektekkel összefüggő közigazgatási hatósági ügyek nemzetgazdasági szempontból kiemelt jelentőségű üggyé nyilvánításáról és az eljáró hatóságok kijelöléséről 
ISSN 2630-886X

18 国 57
BGE 